\title{
ANALISIS BIAYA OPERASIONAL UNTUK MEMPREDIKSI LABA BERSIH PADA PT. HOLCIM INDONESIA Tbk.
}

\author{
Muhammad Faisal $^{1}$, Nurhayati ${ }^{2}$ \\ Muhammadfaisal1357@gmail.com. \\ Sekolah Tinggi Ilmu Ekonomi Bima ${ }^{1}$ \\ Sekolah Tinggi Ilmu Ekonomi Bima
}

\begin{abstract}
This study aims to determine the effect of operating costs on net income at PT. Holcim Indonesia Tbk. This type of research is quantitative with the type of data used is secondary data in the form of the company's income statement for the last 5 years. Data analysis techniques used are operational cost analysis, simple linear regression analysis, correlation coefficient, coefficient of determination and hypothesis testing ( $t$ test 2 parties). The results showed that operational costs did not have a significant effect on net income because this $t$ value was smaller than t table (-1.540 <2.262) with a sig value of 0.221 . Based on the calculation of the correlation coefficient of 0.664 with a strong degree of entanglement and the value of the coefficient of determination of $44.1 \%$ which shows that the contribution of the influence of operating cost variables to net income is $44.1 \%$ and the remaining $55.9 \%$ is influenced by other variables not examined in this study.
\end{abstract}

\section{Keywords: Operating Costs; Net Profit}

\begin{abstract}
Abstrak
Penelitianini bertujuanuntuk mengetahui pengaruh biaya operasional terhadap laba bersih pada PT.Holcim Indonesia Tbk.Jenis penelitian yang digunakan yaitu kuantitatif dengan jenis data yang digunakan adalah data sekunder berupa laporan laba rugi perusahaan selama5 tahun terakhir.Teknik analisis data yang digunakan yaitu analisis biaya operasional, analisisregresilinear sederhana,koofisienkorelasi, koofisiendeterminasidanujihipotesis(uji $t 2$ pihak). Hasil penelitian menunjukkan bahwa biaya operasional tidak berpengaruh signifikan terhadap laba bersih hal ini dikarenakan nilai t hitung lebih kecil dari pada ttabel $(-1,540<2,262)$ dengan nilai sig sebesar 0.221. Berdasarkan hasil perhitungan koofisien korelasisebesar 0,664dengan tingkat ketereratan hubungan yang kuat dan nilai koofisien determinasi sebesar44,1\% yang menunjukkan bahwa kontribusi pengaruhvariabel biaya operasional terhadap laba bersih yaitu sebesar 44,1\% dan sisanya55,9\% dipengaruhi oleh variable lain yang tidak diteliti dalam penelitian ini.
\end{abstract}

\section{Kata Kunci: Biaya Operasional; Laba Bersih.}

\section{PENDAHULUAN}

Laba atau profit adalah salah satu tujuan utama berdirinya setiap badan usaha atau perusahaan, jika tidak mendapatka laba, perusahaan tidak dapat memenuhi tujuan yang lain, pertumbuhan yang terus menerus atau berkembang. Dengan laba, ini membuat perusahaan tumbuh dan berkembang, bisa menggunakan kem- ampuan yang lebih besar, bisa memberikan tingkat kepuasan yang lebih besar pada konsumen, dan perusahaan bisa memperkuat kondisi perekonomian secara keseluruhan (Basu swastha, 2011). Semua perusahaan baik itu peusahaan besar ataupun kecil, biasanya selalu meningkatkan laba yang diperolehnya. Banyak cara akan ditempuh untuk mendapatkan laba yang lebih besar. Perolehan laba bersih salah satunya yang 
dapat digunakan untuk memperoleh laba yang optimal adalah dengan menekan biaya yang akan dikeluarkan perusahaan.

PT Holcim Indonesia Tbk merupakan perusahaan yang bergerak di bidang pembuatan dan pendistribusian semen di dirikan pada tahun 1971, mengingat semakin banyak bertumbuh kembangnya perusahaan-perusahaan baru, oleh karena itu sangat penting bagi PT Holcim Indonesia Tbk ini tetap mempertahankan eksistensi perusahaan dengan mengefisiensi penggunaan modal kerja untuk mendapatkan penjualan yang diharapkan meningkat dari tahun ke tahun.

\section{Tabel 1}

Perkembangan Biaya Operasional Pada PT. Holcim Indonesia Tbk. (Dalam jutaan rupiah)

\begin{tabular}{|c|c|c|c|}
\hline \multirow{2}{*}{ TAHUN } & $\begin{array}{c}\text { BIAYA } \\
\text { DISTRIBUSI }\end{array}$ & $\begin{array}{c}\text { BIAYA } \\
\text { PENJUALAN }\end{array}$ & $\begin{array}{c}\text { BIAYA UMUM \& } \\
\text { ADMINISTRASI }\end{array}$ \\
\hline 2014 & $817.298,00$ & $295.982,00$ & $596.309,00$ \\
\hline 2015 & $889.615,00$ & $322.521,00$ & $603.003,00$ \\
\hline 2016 & $783.302,00$ & $317.457,00$ & $554.434,00$ \\
\hline 2017 & $807.957,00$ & $336.121,00$ & $538.004,00$ \\
\hline 2018 & $838.212,00$ & $393.261,00$ & $403.724,00$ \\
\hline
\end{tabular}

Sumber : idx.co.id

Berdasarkan data biaya-biaya yang dikeluarkan pada PT Holcim Indonesia Tbk mengalami fluktuatif selama 5 tahun terakhir (2014-2015). Pada tahun 2014 biaya PT Holcim Indonesia Tbk, yaitu 1.709.589 milyar rupiah, lalu pada tahun 2015 mengalami peningkatan sebesar 1.815139 milyar rupiah, kemudian mengalami penurunan pada tahun 2016 sebesar 1.655.193 milyar rupiah,pada tahun 2017 mengalami penurunan sebesar 355.944 milyar rupiah dan pada tahun 2018 mengalami peningkatan lagi biaya sebesar 380.003 milyar rupiah. Peningkatan pengeluaran biaya paling besar khususnya pada tahun 2015 karna kenaikan biaya distribusi.

Berdasarkan gambaran fenomena diatas maka penulis tertarik mengkaji dengan melakukan penelitian berjudul "Analisis Biaya Untuk Memprediksi Laba Operasional Pada Pt.Holcim Indonesia Tbk". Tujuan dari penelitian ini adalah untuk mengetahui pengaruh biaya untuk memprediksi laba pada PT. Holcim Indonesia Tbk.

Berdasarkan tujuan peneliti yang akan dicapai, maka penelitian ini akan bermanfaat: (1) dapat memberikan referensi, serta dapat menabah informasi sumbangan pemikiran dan kajian tentang Analisis Biaya Untuk Memprediksi Laba Pada PT.Holcim Indonesia Tbk yang dapat digunakan untuk masa yang akan datang. (2) Dengan adanya penelitian inipenulis diharapkan dapat mempraktekan teori yang diperoleh dan dapat mengaplikasikan nya dilapangan.

\section{TINJAUAN PUSTAKA}

\section{Landasan Teori}

\section{Biaya}

Pengertian biaya menurut Mulyadi (2005:8) mendefinisikan biaya dalam arti luas sebagai berikut: "Biaya adalah pengorbanan sumber ekonomi yang diukur dalam satuan uang, yang telah terjadi atau yang kemungkinan akan terjadiuntuk tujuantertentu."

\section{Biaya Operasinal}

Istilah operasional sering digunakan dalam suatu organisasi yang menghasilkan keluaran output, baik yang berupa barang dan jasa. Secara umum operasional diartikan sebagai suatu usaha, kegiatan atau proses mentransformasikan masukan (input) menjadi hasil keluaran (output).

Menurut Jopie Jusuf (2008:33) yang dimaksud dengan Biaya Operasional adalah 
sebagai berikut: "Biaya Operasinal adalah biaya yang terus dikeluarkan oleh entitas, yang tidak berhubungan dengan aktifitas operasaional perusahaan sehari hari."rumus untuk mencari biaya operasional:

Total Biaya Operasional

= Biaya Distribusi + Biaya Penjualan

+ Biaya Umum \& Administrasi

\section{Laba Bersih}

Bagi semua perusahaan yang berorientasi laba, sudah barang tentu perusahaan tersebut akan selalu meningkatkan labanya, karena jika tidak mungkin perusahaan tersebut akan bangkrut. Dibawah ini ada beberapa pendapat para ahli mengenai laba diantaranya:

Pengertan laba menurut Kuswadi (2007:131)adalah sebagai berikut: "Laba adalah pendapatan dari hasil penjualan dikurangi dengan biaya-biaya pengadaan dan pemasaran."untuk mencari nilai laba bersih dengan rumus:

\section{Laba Bersih = Laba Sebelum Pajak - Pajak Penghasilan}

\section{Pengaruh Biaya Operasinal Terhadap Laba Bersih}

Kuswadi (2007:78) dalam perhitungan laba rugi, besarnya biaya ini akan mengurangi laba atau menambah rugi perusahaan.Umar Juki (2008:9) dalam perhitungan laba rugi, besarnya biaya ini akan mengurang labaatau menambah rugi perusahaan. Tingginya biaya operasi akan membuat peningkatan laba turun, begitu juga jika nilai biaya operasioal rendah maka, peningkatan laba akan naik. Jadi, untuk memperoleh laba tinggi perlu diperhatikan biaya-biaya yang dikeluarkan dan mengedalikannya. Seara efektif, selain itu perusahaan dapat menapai laba yang sesuai dengan yang ingin dicapainya.

\section{HIPOTESIS PENELITIAN}

Diduga ada pengaruh yang signifkan antara Biaya Operasinal Terhadap Laba Bersih pada PT. Holcim Indonesia Tbk.

\section{Hipotesis Statistik}

Ho: $\beta=0$, Tidak ada pengaruh yang signifikan antara Biaya Operasinal terhadap Laba Bersih pada PT. Holcim Indonesia Tbk.

Ha: $\beta \neq 0$, Ada pengaruh yang signifikan antara Biaya Operasinal terhadap Laba Bersih pada PT. Holcim Indonesia Tbk.

\section{Kerangka Berpikir}

Sebagai dasar dalam mengarahkan pemikiran dalam penelitian ini untuk mengatahui pengaruh Biaya Operasinal Terhadap Laba Bersih pada PT. Holcim Indonesia Tbk. Maka digunakan kerangka pemikiran seperti pada gambar dibawah ini:

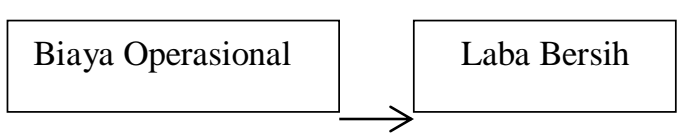

\section{Gambar 2}

Kerangka Berpikir

\section{METODEPENELITIAN}

\section{Jenis Penelitan}

Jenis penelitian yang digunakan dalam penelitian ini adalah penelitian asosiatif yaitu suatu pernyataan yang menunjukan dugaan tentang hubunga antara dua variabel atau lebih (Sugiyono, 2017 : 89). Dalam penelitian ini penulis akan membahas Biaya Untuk Memprediksi Laba Operasional Pada PT.Holcim Indonesia Tbk.

Populasi, Sampel Penelitian, Dan Teknik Sampling Penelitian 
Sugiyono (2013 : 90) mengatakan bahwa Populasi adalah wilayah generalisasi yang terdiri atas obyek/subyek yang mempunyai kuantitas dan karakteristik tertentu yang dapat oleh penelitian untuk dipelajari dan kemudian ditarik kesimpulannya. Populasi yang di gunakan yaitu laporan keuangan tahunan perusahan HOLCIM yang terdaftar dibursa efek Indonesia (BEI) di mulai dari tahun 2001 sampai 2018 yaitu sebanyak 17 tahun.

Menurut (Sugiyono, 2013) Sampel adalah bagian dari jurnal karakteristik yang dimiliki oleh Populasi tersebut. Pengambilan sampel dalam penelitian sebanyak 5 tahun terakhir dari tahun 2014 sampai dengan tahun 2018.

Dalam penelitian ini menggunakan teknik purposive sampling yaitu teknik penentuan Sampel berdasarkan pertimbangan tertentu (Sugiyono : 392).

\section{Instrumen Penelitian Dan Teknik Pengumpulan Data}

Instrumen Penelitian adalah suatu alat yang digunakan untuk mengukur fenomena alam maupun sosial yang diamati (Sugiyono, 2013 :119). Maka instrumen dalam penelitian adalah daftar tabel berupa data biaya operasional pada laporan laba rugi Pt.Holcim Tbk selam 5 (lima) tahun mulai dari tahun 2014 sampai dengan tahun 2018.

Teknikpengumpulan data yang digunakan yaitu dokumentasi dan Studi pustaka (Library Research).

\section{Teknik Analisis Data}

\section{Biaya operasional}

Adapun teknik analisis yang digunakan dalam Penelitian adalah dengan menganalisis biaya operasional dengan menggunakan rumus (Denny Prabu Syaputra ,2018).
Total Biaya Operasional = Biaya Distribusi

+ Biaya Penjualan + Biaya Umum

DanBiaya Administrasi

\section{Laba}

Pengertian Laba Bersih adalah kelebihan seluruh pendapatan atau seluruh biaya atas suatu periode tertentu setelah dikurangi pajak penghasilan dan disajikan dalam bentuk laporan Laba Rugi dengan menggunakan rumus ( Henry Simamora , $2010: 25$ ).

Laba bersih = laba sebelum pajak - pajak penghasilan

\section{Analisis Regresi Linear Sederhana}

Regresi Linear Sederhana memiliki persamaan:

$$
Y=a+b x
$$

Untuk mencari konstata (a) dan koofisien regresi (b) dapat digunakan rumus sebagai berikut :

(Sugiyono,2017: 238-239)

$$
\begin{gathered}
a=\frac{\left(\sum Y\right)\left(\sum X^{2}\right)-\left(\sum X\right)(X Y)}{n \sum X^{2}-\left(\sum X\right)^{2}} \\
b=\frac{n \sum X Y-\left(\sum Y\right)\left(\sum X\right)}{n \sum X^{2}-\left(\sum X\right)^{2}}
\end{gathered}
$$

\section{Analisis Koofisien Korelasi}

Tehnik korelasi ini digunakan untuk mencari hubungan dan membuktikan hipotesis hubugan dua variabel bila data kedu variabel berbentuk interval atau rasio dan sumber data dari dua variabel atau lebih tersebut adalah sama (Sugiyono,2011: 228). Adapun rumus :

$$
r x y=\frac{\sum x y}{\sqrt{\left(\sum x^{2}\right)\left(\sum y^{2}\right)}}
$$




\section{Analisis Koofisien Determinasi}

Dalam analisiskorelasi, terdapat suatu angka yang disebut dengan Koefisien Determinasi, yang besarnya adalah kuadrat dari koefisien korelasi $\left(\mathrm{r}^{2}\right)$. AdapunRumus (Sugiyono, 2017: 154):

$$
K D=\left(r^{2}\right) \times 100 \%
$$

\section{Uji Statistik(UjiT2Pihak)}

Uji $\mathrm{t}$ digunakan untuk mengetahui pengaruh dari masing-masing variable bebas terhadap variable terikat. Untuk melihat pengaruh secara parsial.

Menurut Syofian Siregar (2014 : 383), uji $\mathrm{T}$ dapat dihitung dengan menggunakan rumus sebagai berikut :

$$
\text { thitung }=\frac{r \sqrt{n-2}}{\sqrt{1-(r)}}
$$

\section{HASIL DAN PEMBAHASAN}

Berdasarkan hasil pengolahan data diperoleh hasil sebagai berikut :

\section{Analisis Biaya Operasional}

Untuk mengetahui perkembangan total biaya operasional pada PT Holcim Indonesia Tbk selama 5 (lima) tahun terakhir maka dapat dlihat pada table berikut:

\begin{tabular}{|c|c|c|c|c|}
\hline 2014 & 817.298 .000 & 295.982 .000 & 596.309 .000 & 1.709 .589 .000 \\
\hline 2015 & 889.615 .000 & 322.521 .000 & 603.003 .000 & 1.815 .139 .000 \\
\hline 2016 & 783.302 .000 & 317.457 .000 & 554.434 .000 & 1.655 .193 .000 \\
\hline 2017 & 807.957 .000 & 336.121 .000 & 538.004 .000 & 1.682 .082 .000 \\
\hline 2018 & 838.212 .000 & 393.261 .000 & 403.724 .000 & 1.635 .197 .000 \\
\hline
\end{tabular}

Sumber : Data Sekunder Diolah 2020

Berdasarkan data pada tabel tentang perkembangan perputaran total biaya pada PT.Holcim Indonesia Tbk selama 5 (lima) tahun terakhir yaitu dari tahun 2014 sampai dengan tahun 2018 maka dapat dijelasan bahwa terjadi naik turun perputaran total biaya operasional meskipun tida terlalu signifikan. Hal ini terlihat dari tahun 2014 ke 2015 mengalami kenaikan 1.709.589 menjadi 1.215.139. kemudian mengalami penurunan tahun 2016 sebesar 1.655.139. selanjudnya mengalami kenaikan lagi sebesar 1.682.082. kemudian pada tahun 2018 mengalami penurunan sebesar 1.635.197. penurunan yang terjadi pada tahun 2016 dan 2018 dikarenakan perusahaan melakukan efisiensi biaya khususnya biaya umum dan administrasi.

\section{Analisis Laba Bersih}

Untuk melihat perkembangan total laba pada PT Holcim Indonesia Tbk selama 5 (lima) tahun terakhir maka dapat dlihat pada tabel berikut :

Tabel 3

Perkembangan laba bersih pada PT. Holcim Indonesia Tbk.

\section{Tabel 2}

Perkembangan Biaya Operasional Pada

\begin{tabular}{|c|c|c|c|c|c|c|}
\hline & & (Dalar & jutaan ru & ah) & 2015 & 144.983 .000 \\
\hline & & & & & 2016 & 284.584 .000 \\
\hline TuU & BIAYA & BIAYA & & Total Biaya & 2017 & 863.644 .000 \\
\hline IAHUN & DISTRIBUSI & PENJUALAN & $\stackrel{\text { ¿ }}{\text { ADMINISTR ASI }}$ & Operasiona & 2018 & 1.026 .381 .000 \\
\hline & & & & & Total & 2.972.004.000 \\
\hline
\end{tabular}
PT. Holcim Indonesia Tbk. 
Berdasarkan tabel tersebut terlihat bahwa nilai Laba bersih dari tahun 2014 sampai dengan 2018 pada PT. Holcim Indonesia Tbk mengalami fluktuatif naik dan turun. Hal ini dikarenakan akibat dari biaya operasional perusahaan yang mengalami fluktuatifpula.

\section{Analisis Regresi Linear Sederhana}

Regresi Linear Sederhana didasarkan pada hubungan fungsional atau pun kausal satu variabel independen dengan satu variabel dependen.

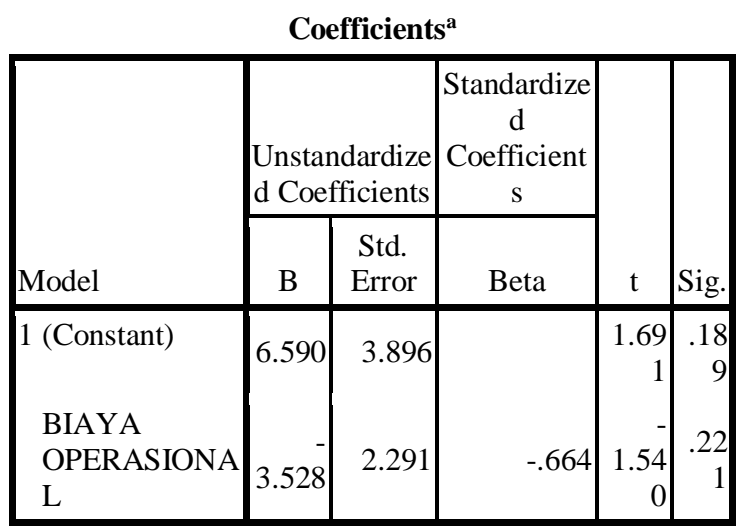

Berdasarkan output SPSS diatas di temukan nilai constant sebesar 6,590 dan nilai koofisien regresi(b)=-3,528 sehingga dapat dibuat persamaan regresi sebagai berikut : $\mathbf{Y}=\mathbf{0 , 3 9 1}-\mathbf{0 , 5 7 2 X}$

\section{Analisis koefisien Korelasi}

Teknik korelasi ini digunakan untuk mencari hubungan dan membuktikan hipotesis hubungan dua variabel. (Sugiyono,2017).

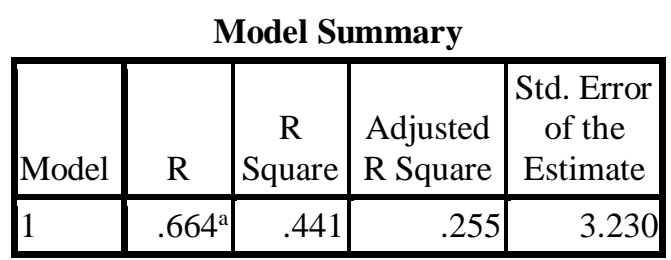

a. Predictors: (Constant), BIAYA

OPERASIONAL

Berdasarkan hasil analisis spss diatas,maka diperoleh nilai korelasi sebesar
0,664 yang berarti bahwa tingkat keeratan hubungan antara Biaya Operasional terhadap laba bersih pada PT.Holcim Indonesia Tbk berada pada tingkat yang kuat.

\section{Analisis Koefisien Determinasi}

Dalam analisis korelasi, terdapat suatu angka yang disebut dengan Koefisien Determinasi,yang besarnya adalah kuadrat darikoefisien korelasi $\left(\mathrm{r}^{2}\right)$.

\section{Model Summary}

\begin{tabular}{|l|l|r|r|r|}
\hline Model & R & $\begin{array}{c}\text { R } \\
\text { Square }\end{array}$ & $\begin{array}{c}\text { Adjusted } \\
\text { R Square }\end{array}$ & $\begin{array}{c}\text { Std. Error } \\
\text { of the } \\
\text { Estimate }\end{array}$ \\
\hline 1 & $.664^{\mathrm{a}}$ & .441 & .255 & 3.230 \\
\hline
\end{tabular}

a. Predictors: (Constant), BIAYA OPERASIONAL

Berdasarkan hasil analisis spss diatas,diperoleh nilai Koefisien Determinasi $\left(\mathrm{R}^{2}\right)$ sebesar 0,441yang berarti bahwa kontribusi pengaruh Biaya Operasional terhadapLaba Bersih padaPT. Holcim IndonesiaTbk adalah sebesar $44,1 \%$, sedangkan sisanya $55,9 \%$ dipengaruhi oleh variabel lain yang tidak diteliti dalam penelitian ini.

\section{Uji Statistik(two tail)}

Uji t digunakan untuk mengetahui pengaruh dari masing-masing variabel bebas terhadap variable terikat. Berdasarkan hasil pengolahan data dengan menggunakan software SPSS versi 23 maka didapatkan hasil sebagai berikut : 


\section{Coefficients $^{\mathrm{a}}$}

\begin{tabular}{|c|c|c|c|c|c|}
\hline \multirow[b]{2}{*}{ Model } & \multicolumn{2}{|c|}{$\begin{array}{l}\text { Unstandardize } \\
\text { d Coefficients }\end{array}$} & $\begin{array}{c}\text { Stand } \\
\text { ardize } \\
\mathrm{d} \\
\text { Coeff } \\
\text { icient } \\
\text { s }\end{array}$ & \multirow[b]{2}{*}{$\mathrm{t}$} & \multirow[b]{2}{*}{ Sig. } \\
\hline & B & $\begin{array}{l}\text { Std. } \\
\text { Error }\end{array}$ & Beta & & \\
\hline $1 \quad$ (Constant) & 6.590 & 3.896 & & 1.691 & .189 \\
\hline $\begin{array}{l}\text { BIAYA } \\
\text { OPERASI } \\
\text { ONAL }\end{array}$ & -3.528 & 2.291 & -.664 & -1.540 & .221 \\
\hline
\end{tabular}

Berdasarkan hasil analisis spss diatas,maka diperoleh nilai t-hitung sebesar $-1,540$ dan tingkat signifikansi sebesar 0,221 serta nilai t-tabel sebesar 2,262.

Berdasarkan perolehan nilai tersebut maka $\mathrm{H}_{0}$ diterima dan $\mathrm{H}_{\mathrm{a}}$ ditolak yang artinya bahwa tidak ada pengaruh yang signifikan antara Biaya Operasional terhadap Laba Bersih pada PT.Holcim IndonesiaTbk ha ini berdasarkan nila iNilai t hitung $<\mathrm{t}$ tabel $(-1,540<2,262)$.

\section{KESIMPULAN}

Dari hasil penelitian mengenai pengaruh Biaya Operasional terhadap Laba Bersih pada PT.Holcim IndonesiaTbk, maka penulis dapat menarik kesimpulan sebagai berikut.

Biaya Operasional berpengaruh terhadap laba bersih. Nilai korelasi bertanda positif, ini berarti terdapat hubungan antara biaya operasional dengan laba bersih. Sehingga pada penelitian ini biaya operasional tidak akan terlalu berdamapak besar terhadap laba bersih pada perusahaan semen yang terdaftar dibursa efek indonesia. Dari hasil pengujian persial dapat disimpulkan bahwa variabel Biaya Operasional terhadap Laba Bersih memiliki kontribusi pengaruh positif.

\section{SARAN}

Peneliti diharapkan dapat berguna bagi perusahaan khususnya PT. Holcim Indonesia Tbk, untukmempredksi perkembangan laba di masa yang akan datang serta untuk menentukan pertumbuhan perusahaan kedepan dan salah satu faktoryang mencerminkan kondisi dan kinerja keuangan perusahaan.Bagi para analis, investor dan menajemen hasil penelitian ini bisa diharapan memberikan pertimbangan dalam pengambilan keputusan investasi serta untuk menentukan kebijakan-kebijakan dalm perusahaan sekaligus mengevaluasihasil kinerja manajemen melalui perhitungan terhadapprediksi pertumbuhan laba.

\section{PENUTUP}

Bagi peneliti selanjutnya diharapkan untuk dapat melakukan peneitian lebih lanjut mengenai faktor yang memprediksi laba pada bank yang berbeda. Hal ini berguna untuk menguji temuan faktor yang menyebabkan perubahan laba dalam penelitin ini secara lebih luas.Kemudian untuk menambah pengetahuan dan pengalaman peneliti dalam meneliti tentang menentukan laba dan juga sebagai bentukpengaplikasian teori yang diperoeh di bangku kuliah serta sebagai bahan peajaran dan eeahan masalah bagi peneliti.

\section{DAFTAR PUSTAKA}

Henry Simarsono, 2010. Akuntansi Keuangan Menengah. Yogyakarta.

Mulyadi. (2009). Akuntansi Biaya. Edisi 5. Yogyakarta.

(2012). Akuntansi Biaya. Edisi 5. Yogyakarta: UUP STMI YKPN.

Prabu, W. (2018). Pengaruh Biaya Produksi dan Biaya Operasional Terhadap Laba Bersih. Fakultas Ekonomi dan Bisnis. Universitas Telkom. 
Indonesian Journal Of Strategic Management Vol 3, Issue 2, Agustus 2020

Sugiyono, 2012. Metodologi Penelitian Administrasi. Alfabeta : Bandung.

Warner, R. M. (2013). Analisis Laporan Keuangan, Proyeksi dan Valuasi Saham, Jakarta. Salemba Empat
p-ISSN 2614-5391, e-ISSN 2614-2406

https://journal.uniku.ac.id/index.php/ijsm

Wayan B. W., Anjuman Z., \& Kadek, R. S. (2014). pengaruh volume penjualan mente dan biaya operasional terhadap laba bersih pada UD. Agung Esha. Singaraja, Indonesia. 